\title{
Computational studies of the structure of aldazines and ketazines. Part 1. Simple compounds
}

\author{
Ibon Alkorta, ${ }^{*}$ Fernando Blanco, ${ }^{\ddagger}$ and José Elguero \\ Instituto de Química Médica, CSIC, Juan de la Cierva, 3, E-28006 Madrid, Spain \\ ${ }^{\ddagger}$ On leave from the University of Valencia (Faculty of Pharmacy) \\ E-mail: $\underline{\text { bbon@iqm.csic.es }}$
}

Dedicated to Prof. Guy Queguiner on the occasion of his 70th anniversary

\begin{abstract}
The molecular structure of seven simple aliphatic and aromatic aldazines and ketazines has been calculated at the B3LYP/6-311++G** computational level. Geometries, E/Z- isomerism and conformation of the compounds have been compared with the available data (electron diffraction, X-ray crystallography). IR and Raman spectra have been calculated and compared with experimental ones.
\end{abstract}

Keywords: Aldazines, ketazines, isomerism, B3LYP, 6-311++ $\mathrm{G}^{* *}$, IR C=N stretching

\section{Introduction}

The term azine has two meanings in chemistry: in heterocyclic chemistry, azines are aromatic six-membered rings containing from one (pyridine $\mathbf{I})$ to six $\mathrm{N}$ atoms (hexazine). In alicyclic chemistry, azines are the compounds resulting from the reaction of two molecules of a carbonyl compound (or, less frequently, of two different carbonyl compounds) with hydrazine. The compounds are called aldazines II or ketazines III depending on whether the carbonyl compound is an aldehyde or a ketone, respectively.

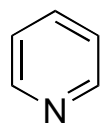

|

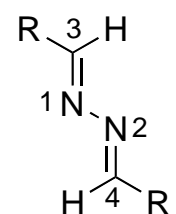

II

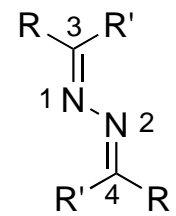

III 
This ambiguity makes the search in databases more difficult. Some of us published in the past several papers devoted to azines in the second meaning of the definition (from now on the word azine will be restricted to compounds II and III). ${ }^{1}$ Azines have been the subject of several studies with special emphasis on their use as synthons, ${ }^{1 \mathrm{i}, 1 \mathrm{j}, 2}$ on their mesogenic (as such or with metals, metallomesogens) and NLO properties, ${ }^{3}$ as well as for their interesting structural properties. ${ }^{4}$ Formaldazine $\mathbf{1}$ occupies a special position and it is frequently considered a diazabutadiene. ${ }^{5}$ In this first paper devoted to azines, we will report the results obtained with compounds 1-7 (Scheme 1).<smiles>C=N/N=C\C</smiles>

1

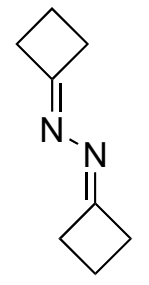

4

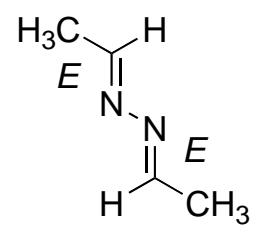

$2 a$

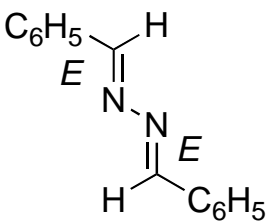

$5 a$<smiles>CC([18OH])=NN=C(C)c1ccccc1</smiles>

$6 a$

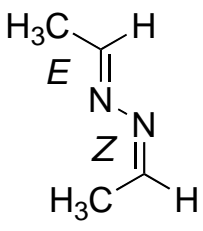

2b

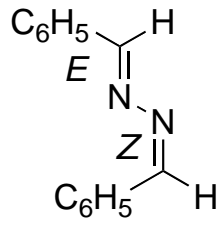

$5 b$

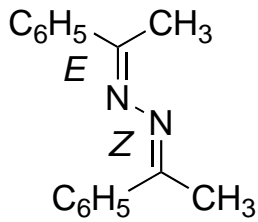

$6 b$

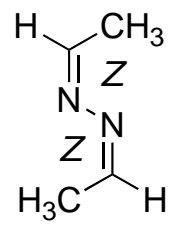

2c<smiles>[Z6]c1ccccc1/N=C/[3H]</smiles>

$5 c$<smiles>[Z20]c1ccccc1</smiles>

$6 c$<smiles>CC(C)=NN=C(C)C</smiles>

3<smiles>c1ccc(C(=NN=C(c2ccccc2)c2ccccc2)c2ccccc2)cc1</smiles>

7

Scheme 1. Aldazines $(1,2,5)$ and ketazines $(3,4,6,7)$.

For aldazines II (compounds $\mathbf{2}$ and 5) and for these ketazines III where $\mathrm{R} \neq \mathrm{R}$ ' (compound 6) three configurational isomers are possible: the $E, E(\mathbf{a})$, the $E, Z$ (b) and the $Z, Z$ (c). All of them have been calculated.

\section{Computational details}

The optimization of the geometries and the calculation of frequencies (to evaluate the minimum nature of the geometries obtained) of the structures were first optimized at the B3LYP/6-31G* and then reoptimized at the $\mathrm{B} 3 \mathrm{LYP} / 6-311++\mathrm{G}^{* *}$ computational level ${ }^{6-8}$ within the Gaussian-03 
package. ${ }^{9}$ The directly calculated frequencies were scaled by a factor of $0.9613^{10}$ to account for the overestimation of vibrational frequencies at the B3LYP/6-31G* level.

\section{Results and Discussion}

\section{Geometries}

The geometries of the $\mathrm{C}=\mathrm{N}-\mathrm{N}=\mathrm{C}$ fragments are reported in Table 1 .

Table 1. Geometries $\left(\AA,{ }^{\circ}\right)$, absolute energies (Hartree), relative energies $\left(\mathrm{kJ} \mathrm{mol}^{-1}\right)$ and dipole moments (D)

\begin{tabular}{llllllllll}
\hline Azine & C3-N1 & N1-N2 & N2-C4 & C3N1N2 & N1N2C4 & C3N1N2C4 & E & $E_{\text {rel }}$ & $\mu$ \\
\hline $\mathbf{1}$ & 1.272 & 1.416 & 1.272 & 111.9 & 111.9 & 180.0 & -188.1053 & ---- & 0.0 \\
$\mathbf{2 a}$ & 1.275 & 1.411 & 1.275 & 112.4 & 112.4 & 180.0 & -266.7761 & $\mathbf{0 . 0}$ & 0.0 \\
$\mathbf{2 b}$ & 1.279 & 1.411 & 1.276 & 114.4 & 111.8 & 180.0 & -266.7728 & 8.8 & 0.7 \\
$\mathbf{2 c}$ & 1.278 & 1.386 & 1.278 & 116.3 & 116.3 & 135.8 & -266.7700 & 16.2 & 1.8 \\
$\mathbf{3}$ & 1.284 & 1.395 & 1.284 & 115.4 & 115.4 & 153.0 & -345.4358 & ---- & 1.16 \\
$\mathbf{4}$ & 1.270 & 1.414 & 1.270 & 112.3 & 112.3 & 177.8 & -421.5902 & ---- & 0.08 \\
$\mathbf{5 a}$ & 1.284 & 1.391 & 1.284 & 112.6 & 112.6 & 180.0 & -650.3495 & $\mathbf{0 . 0}$ & 0.0 \\
$\mathbf{5 b}$ & 1.287 & 1.383 & 1.284 & 117.6 & 113.2 & 154.3 & -650.3415 & 21.1 & 1.7 \\
$\mathbf{5 c}$ & 1.286 & 1.354 & 1.286 & 121.0 & 121.0 & 130.4 & -650.3367 & 33.5 & 2.2 \\
$\mathbf{6 a}$ & 1.290 & 1.371 & 1.290 & 117.3 & 117.3 & 142.9 & -729.0017 & $\mathbf{0 . 0}$ & 1.2 \\
$\mathbf{6 b}$ & 1.291 & 1.376 & 1.291 & 116.6 & 117.8 & 151.4 & -728.9963 & 14.0 & 1.2 \\
$\mathbf{6 c}$ & 1.290 & 1.376 & 1.290 & 118.2 & 118.2 & 150.9 & -728.9904 & 29.6 & 1.2 \\
$\mathbf{7}$ & 1.295 & 1.371 & 1.295 & 117.0 & 117.0 & 153.6 & -1112.5579 & --- & 0.8 \\
\hline
\end{tabular}

The structure of 1 has been determined by electron diffraction ${ }^{5 \mathrm{~d}}$ and then calculated (HF/6$31 \mathrm{G}^{*}$ ) by Bachrach and Liu. ${ }^{5 \mathrm{de} e}$ A comparison of these structures with that reported in Table 1 is represented in Scheme 2. The superiority of the B3LYP/6-311++G** calculations is evident. Only MP2 and QCISD gave comparable results. ${ }^{5 \mathrm{f}}$

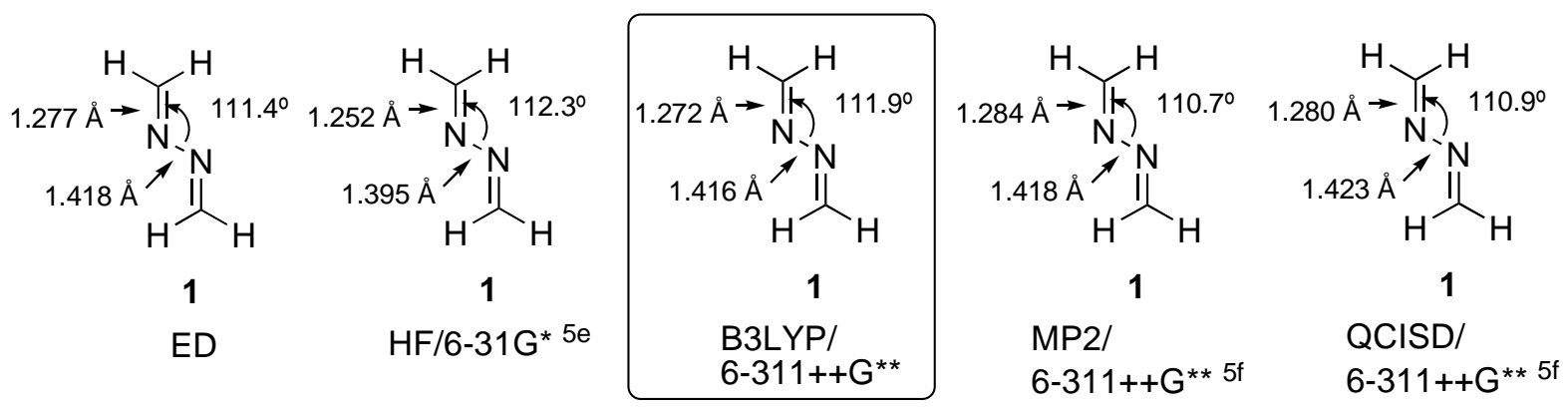


Scheme 2. The geometry of 2,3-diaza-1,3-butadiene (formaldazine). ED stands for the experimentally determined (Electron Diffraction) geometry

The structures of the three azines of Scheme $1(5,6$ and 7) have been determined by X-ray crystallography.

Table 2. Geometries $\left(\AA,{ }^{\circ}\right)$ of benzalazines 5, 6 and 7

\begin{tabular}{lllllll}
\hline Azine & C3-N1 & N1-N2 & N2-C4 & C3N1N2 & N1N2C4 & C3N1N2C4 \\
\hline $\mathbf{5 a}$ & 1.284 & 1.391 & 1.284 & 112.6 & 112.6 & 180.0 \\
$\mathbf{5 b}$ & 1.287 & 1.383 & 1.284 & 117.6 & 113.2 & 154.3 \\
$\mathbf{5 c}$ & 1.286 & 1.354 & 1.286 & 121.0 & 121.0 & 130.4 \\
BZAZIN02 & 1.275 & 1.417 & 1.275 & 11.8 & 111.8 & 180.0 \\
BZAZIN11 & 1.269 & 1.413 & 1.269 & 112.6 & 112.6 & 180.0 \\
$\mathbf{6 a}$ & 1.290 & 1.371 & 1.290 & 117.3 & 117.3 & 142.9 \\
$\mathbf{6 b}$ & 1.291 & 1.376 & 1.291 & 116.6 & 117.8 & 151.4 \\
$\mathbf{6 c}$ & 1.290 & 1.376 & 1.290 & 118.2 & 118.2 & 150.9 \\
LIKHIW & 1.278 & 1.403 & 1.278 & 115.4 & 114.5 & 138.7 \\
LIKHIW01 & 1.285 & 1.396 & 1.286 & 115.6 & 114.4 & 139.7 \\
7 & 1.295 & 1.371 & 1.295 & 117.0 & 117.0 & 153.6 \\
ZOSLUO & 1.286 & 1.404 & 1.286 & 116.4 & 116.4 & 132.5 \\
ZOSLUO01 & 1.287 & 1.394 & 1.287 & 116.4 & 116.4 & 130.0 \\
ZOLUO02 & 1.294 & 1.395 & 1.294 & 116.4 & 116.4 & 129.8 \\
\hline
\end{tabular}

Three aspects are worth discussing:

1) The calculated geometries are similar to the experimental ones; in general, the azadiene system is more delocalized in the calculations than in the X-ray structures. The NN/NC ratios are: 1.083 (5a) vs. 1.114 (BZAZIN11); 1.063 (6a) vs. 1.086 (LIKHIW01), and 1.059 (7) vs. 1.078 (CCDC 299197). The angles are well reproduced and the important torsion angle is identical in 5a (planar), a little lower (less flat) in LIKHIW01 compared with 6a (ratio 0.98) and clearly lower in ZOSLUO (average of three structures) compared with 7 (ratio 0.85). These increased deformation from the plane are probably crystal-packing effects.

2) We have used Taft Steric parameter $\mathrm{E}_{\mathrm{s}}\left(0\right.$ for $\mathrm{H},-1.24$ for $\mathrm{CH}_{3}$ and -3.72 for $\left.\mathrm{C}_{6} \mathrm{H}_{5}\right) .{ }^{11}$ Although the correlations were not satisfying, the torsion angle only depends on the internal substituents. There is also a significant relationship between the torsion angle and the angles at the $\mathrm{N}$ atoms (the average in the case of non-symmetric compounds): torsion angle $=875-6.2$ NNC angle, $r^{2}=0.82$.

3 ) In the case of 4 , the ring strain localized the azadiene conjugated system. If we compare 3 with 4 , the $\mathrm{NN} / \mathrm{NC}$ ratios are 1.086 and 1.113 , respectively. The torsion angle is very different, $153^{\circ}$ for 3 and $178^{\circ}$ for 4 , due to the less steric demand of the methylene groups of the four 
membered rings. This azine (CAS RN 72593-07-8), first prepared in $1953,{ }^{12 a}$ has only been described twice. ${ }^{2 \mathrm{k}, 12 \mathrm{~b}}$

4) Compounds 1 and 3 have been calculated at the MP2/6-31G* level by Kobychev et al. ${ }^{5 \mathrm{~g}}$ Their geometries are similar to those we have reported in Table 2. Besides, they have calculated the energy curve about the $\mathrm{N}-\mathrm{N}$ bond rotation.

\section{Infrared and Raman $\mathbf{C}=\mathbf{N}$ stretchings.}

The normal mode frequencies and corresponding vibrational assignments have been carried out theoretically at the B3LYP/6-31G* level. Raman and infrared stretchings of compounds of Scheme 1. In general, the symmetric vibrations are observed in the Raman spectra while the asymmetric ones in the infrared one. In Figure 1 we have reported the case of acetaldazine $2 \mathbf{a}$.

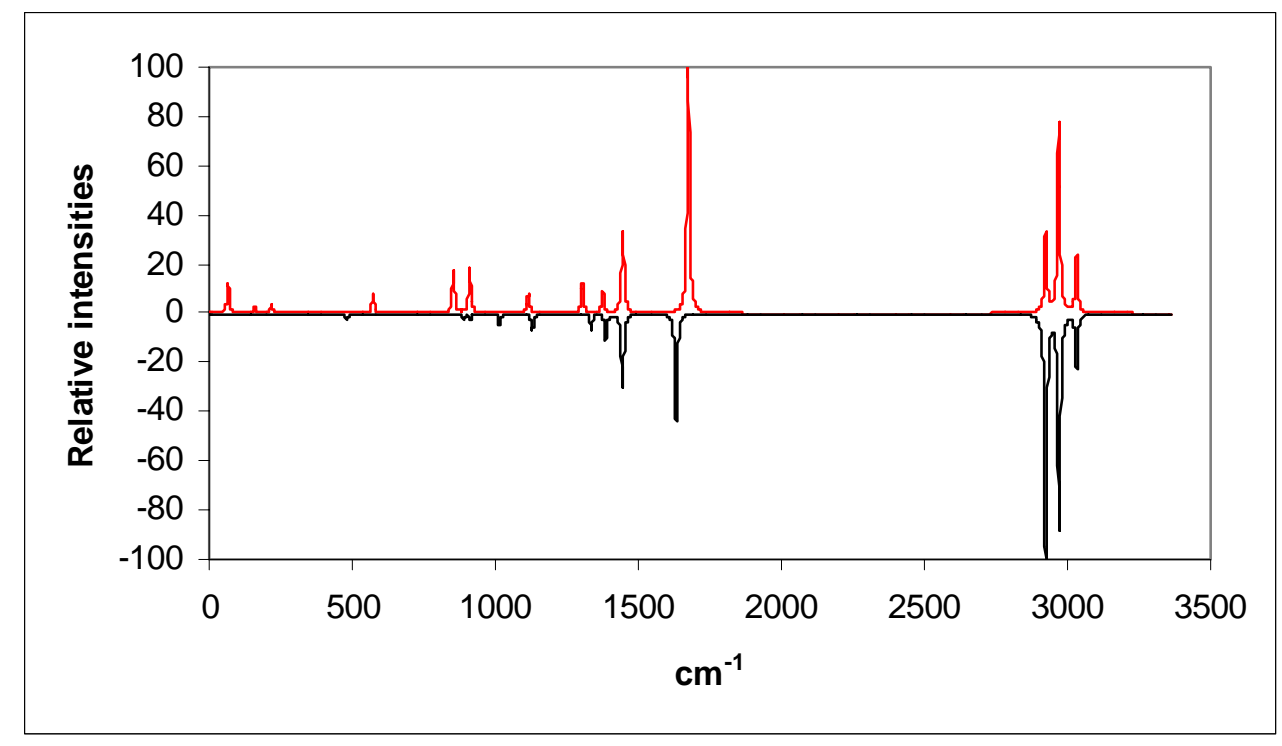

Figure 1. Infrared (up in red) and Raman (down in black) calculated stretchings of 2a: relative intensities and band positions (in $\mathrm{cm}^{-1}$ ).

The experimental study of this compound (pure liquid, both IR and Raman) has shown that the molecule has a $C_{2 h}$ symmetry, i.e. either 2a or 2c. ${ }^{1 \mathrm{~g}}$ Theoretical calculations prove that 2a is more stable than 2c (Table 1). 


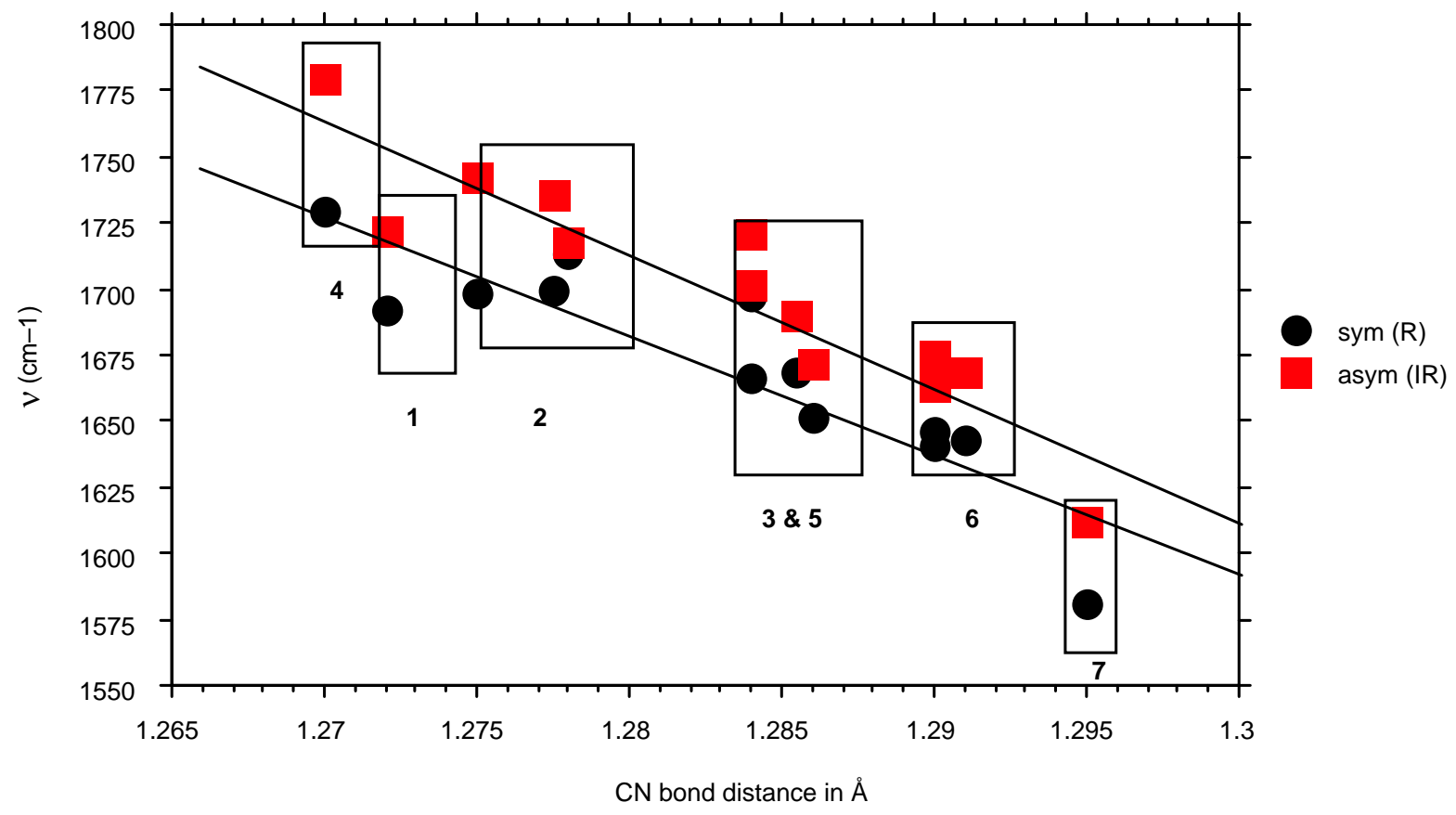

Figure 2. Symmetric (Raman, black) and antisymmetric (IR, red) stretchings $\left(v, \mathrm{~cm}^{-1}\right)$ of the $>\mathrm{C}=\mathrm{N}-\mathrm{N}=\mathrm{C}<$ fragments of azines 1 to 7 against the corresponding $\mathrm{CN}$ bond distance $(\AA)$.

In Figure 2 we have plotted the calculated stretchings vs. the calculated $\mathrm{CN}$ distances. The extreme positions are occupied by cyclobutanone azine 4 and benzophenone azine 7 . The $\mathrm{C}=\mathrm{N}$ stretching band of azines $2 \mathbf{a}$ and $\mathbf{5 a}$ has been reported by Frederickson. ${ }^{13}$ They appear at 1651 (liquid) and $1625\left(\mathrm{CHCl}_{3}\right.$ solution). According to our calculations (gas phase) they should appear at 1674.5 and $1636.2 \mathrm{~cm}^{-1}$.

\section{Energies}

The relative energies of Table 1 can be discussed using Taft's steric effects or a presence absence matrix (Free-Wilson). In the first case we obtained $E_{r e l}=7.1-3.5 E_{s}(Z)+1.5 \mathrm{E}_{\mathrm{s}}(E), n=9, r^{2}=$ 0.92 and in the second one $E_{\text {rel }}=12.0-4.9 \mathrm{Me}(E)+1.2 \mathrm{Me}(Z)-6.3 \mathrm{Ph}(E)+12.5 \mathrm{Ph}(Z), n=$ $9, r^{2}=0.97$. Both equations are similar and correspond to the fact that substituents in the $Z$ position destabilize the compound (more for the bulkier $\mathrm{Ph}$ than the smaller Me) whereas in the $E$ - position the effects are just the opposite.

We have already shown that in the solid state the isomers present are 5a (BZAZIN) and 6a (LIKHIW). In solution, the barriers to $E / Z$ isomerization about the $\mathrm{C}=\mathrm{N}$ bond are weak enough for the equilibrium to be reached inmediately. ${ }^{1 \mathrm{~d}}$ Experiments at $60 \mathrm{MHz}$ with pure compounds have established that in the case of benzalazine only 5a is present in solution (that means that less than $2 \%$ of the other isomers could be present) while in the case of acetaldazine, the mixture was $85 \%$ of $\mathbf{2 a}-15 \%$ of $\mathbf{2 b}$ (2c not observed, i.e. less that $2 \%$ ). ${ }^{1 \mathrm{f}} \mathrm{A} 85 / 15$ mixture corresponds at 
$300 \mathrm{~K}$ to a difference of $4.3 \mathrm{~kJ} \mathrm{~mol}^{-1}$, which is in reasonable good agreement with the results Table 1 taking into account that the differences in dipole moments are weak. In the case of $\mathbf{5}$, isomer $5 \mathbf{b}$ lies $21.1 \mathrm{~kJ} \mathrm{~mol}^{-1}$ higher in energy than $\mathbf{5 a}$.

\section{Conclusions}

This paper reports the first attempt to theoretically study azines (with the exception, mentioned above, of formaldazine 1). Geometries, E/Z isomerism and vibrational aspects have been computed, being in reasonable agreement with experimental data, when available.

\section{Acknowledgements}

This work was carried out with financial support from the Ministerio de Ciencia y Tecnología (Projects No. BQU2003-01251 and CTQ2006-14487-C02-01/BQU) and Comunidad Autonoma de Madrid (Project MADRISOLAR, ref. S-0505/PPQ/0225). Thanks are given to the CTI (CSIC) for allocation of computer time.

\section{References and Footnotes}

1. (a) Arnal, E.; Elguero, J.; Jacquier, R.; Marzin, C.; Wilde, J. Bull. Soc. Chim. Fr. 1965, 877. (b) Elguero, J.; Jacquier, R.; Marzin, C. Bull. Soc. Chim. Fr. 1967, 3005. (c) Berthou, J.; Elguero, J.; Jacquier, R.; Marzin, C.; Rerat, C. Comp. Rend. Acad. Sci. Ser. C 1967, 356, 513. (d) Elguero, J.; Jacquier, R.; Marzin, C. Bull. Soc. Chim. Fr. 1968, 713. (e) Elguero, J.; Jacquier, R.; Marzin, C. Bull. Soc. Chim. Fr. 1969, 1367. (f) Elguero, J.; Jacquier, R.; Marzin, C. Bull. Soc. Chim. Fr. 1969, 1374. (g) Tabacik, V.; Pellegrin, V.; Elguero, J.; Jacquier, R.; Marzin, C. J. Mol. Struct. 1971, 8, 173. (h) Elguero, J.; Jacquier, R.; Berthou, J. Bull. Soc. Chim. Fr. 1973, 3303. (i) Burger, K.; Schikaneder, H.; Elguero, J. Tetrahedron Lett. 1975, 2911. (j) Burger, K.; Schikaneder, H.; Hein, F.; Elguero, J. Tetrahedron 1979, 35, 389. (k) Marcos, M.; Meléndez, E.; Serrano, J. L.; Elguero, J.; Phan Tan Luu, R.; Mathieu, D. An. Quim. 1983, 70B, 664. (1) Marcos, M.; Meléndez, E.; Serrano, J. L.; Mathieu, D.; Phan Tan Luu, R.; Elguero, J. Bull. Soc. Chim. Belg. 1983, 92, 429. (m) Serrano, J. L.; Marcos, M.; Meléndez, E.; Albano, C.; Wold, S.; Elguero, J. Acta Chem. Scand. 1985, B39, 329. (n). Elguero, J.; Jaime, C.; Marcos, M.; Meléndez, E.; SánchezFerrando, F.; Serrano, J. L. J. Mol. Struct. (Theochem) 1987, 150, 1.

2. (a) Gieren, A.; Narayanan, P.; Burger, K.; Thenn, W. Angew. Chem. Int. Ed. 1974, 13, 474.

(b) Gieren, A.; Narayanan, P.; Burger, K.; Thenn, W. Angew. Chem. Int. Ed. 1974, 13, 475.

(c) Evans, S.; Gearhart, R. C.; Guggenberger, L. J.: Schweizer, E. E. J. Org. Chem. 1977, 
42, 452. (d) Burger, K.; Schickaneder, H.; Hein, F.; Gieren, A.; Lamm, V.; Engelhardt, H. Liebig's Ann. Chem. 1982, 845-852. (e) Schweizer, E. E.; Hayes, J. E.; Hirwe, S. N.; Rheingold, A. L. J. Org. Chem. 1987, 52, 1319. (f) Schweizer, E. E.; Hayes, J. E.; Lee, K. J.; Rheingold, A. L. J. Org. Chem. 1987, 52, 1324. (g) Schweizer, E. E.; Hayes, J. E.; Rheingold, A. L.; Wei, X. J. Org. Chem. 1987, 52, 1810. (h) Görgényi, M.; Seres, L. Tetrahedron Lett. 1990, 31, 6447. (i) Schweizer, E. E.; Cao, Z.; Rheingold, A. L.; Bruch, M. J. Org. Chem. 1993, 58, 4339. (j) Ohff, A.; Zippel, T.; Arndt, P.; Spannenberg, A.; Kempe, R.; Rosenthal, U. Organometallics 1998, 17, 1649. (k) El-Alali, A.; Al-Kamali, A. S. Can. J. Chem. 2002, 80, 1293. (1) Cohen, R.; Rybtchinski, B.; Gandelman, M.; Shimon, L. J. W.; Martin, J. M. L.; Milstein, D. Angew. Chem. Int. Ed. 2003, 42, 1949. (m) Deun, R. V.; Parac-Vogt, T. N.; Van Hecke, K.; Van Meervelt, L. V.; Binnemans, K.; Guillon, D.; Donnio, B. J. Mater. Chem. 2003, 13, 1639. (n) Lim, Y.-G.; Koo, B. T. Tetrahedron Lett. 2005, 46, 385. (o) Carmeli, M.; Rozen, S. Tetrahedron Lett. 2006, 47, 763. (p) Verner, J.; Potácek, M. Molecules 2006, 11, 34. (q) Nanjundaswamy, H. M.; Pasha, M. A. Synth. Comm. 2006, 36, 3161. (r) Burger, K.; Hennig, L.; Zeika, O.; Lux, A. Heterocycles 2006, $67,443$.

3. (a) Metallomesogens, Serrano, J. L., Ed. VCH: Weinheim, 1996. (b) Espinet, P.; Etxebarria, J.; Marcos, M.; Pérez, J.; Ramón, A.; Serrano, J. L. Angew. Chem. Int. Ed. 1989, 28, 1065. (c) Espinet, P.; Lalinde, E.; Marcos, M.; Pérez, J.; Serrano, J. L. Organometallics 1990, 9, 555. (d) Marcos, M.; Serrano, J. L.; Sierra, T.; Giménez, M. J. Angew. Chem. Int. Ed. 1992, 31, 1471. (e) Marcos, M.; Serrano, J. L.; Sierra, T.; Giménez, M. J. Chem. Mater. 1993, 5, 1332. (f) Moreno-Mañas, M.; Pleixats, R.; Andreu, R.; Garín, J.; Orduna, J.; Villacampa, B.; Levillain, E.; Sallé, M. J. Mater. Chem. 2001, 11, 374.

4. (a) Lai, E. C. K.; Mackay, D.; Taylor, N. J.; Watson, K. N. Can. J. Chem. 1988, 66, 2839. (b) Chen, G. S.; Wilbur, J. K.; Barnes, C. L.; Glaser, R. J. Chem. Soc. Perkin Trans. 2 1995, 2311. (c) Takahashi, H.; Kubo, K.; Takechi, H.; Matsumoto, T.; Ideta, K. J. Oleo Sci. 2006. 55, 483. (d) Wolstenholme, D. J.; Cameron, T. S. J. Phys. Chem. (A) 2006, 110, 8970.

5. (a) Ogilvie, J. F. Chem. Commun. 1965, 359. (b) Ogilvie, J. F.; Cole, K. C. Spectrochim. Acta 1971, 27A, 877. (c) Bondybey, V. E.; Nibler, J. W. Spectrochim. Acta, Part A 1973, $29,645$. (d) Hagen, K.; Bondybey, V.; Hedberg, K. J. Am. Chem. Soc. 1977, 95, 1365. (e) Bachrach, S. M.; Liu, M. J. Am. Chem. Soc. 1991, 113, 7929 and references therein. (f) Glaser, R.; Lewis, M.; Wu, Z. J. Mol. Model. 2000, 6, 86. (g) Kobychev, V. B.; Vitkovskaya, N. M.; Pavlova, N. V.; Schmidt, E. Yu.; Trofimov, B. A. J. Struct. Chem. 2004, 45, 748.

6. (a) Becke, A. D. Phys. Rev. A 1988, 38, 3098; (b) Becke, A. D. J. Chem. Phys. 1993, 98, 5648; (c) Lee, C.; Yang, W.; Parr, R. G. Phys. Rev. B 1988, 37, 785.

7. Hariharan, P. A.; Pople, J. A. Theor. Chim. Acta 1973, 28, 213.

8. (a) Ditchfield, R.; Hehre, W. J.; Pople, J. A. J. Chem. Phys. 1971, 54, 724. (b) Frisch, M. J.; Pople, J. A.; Krishnam, R.; Binkley, J. S. J. Chem. Phys. 1984, 80, 3265.

9. Gaussian 03, Frisch, M. J.; Trucks, G. W.; Schlegel, H. B.; Scuseria, G. E.; Robb, M. A.; Cheeseman, J. R.; Montgomery, Jr., J. A.; Vreven, T.; Kudin, K. N.; Burant, J. C.; Millam, 
J. M.; Iyengar, S. S.; Tomasi, J.; Barone, V.; Mennucci, B.; Cossi, M.; Scalmani, G.; Rega, N.; Petersson, G. A.; Nakatsuji, H.; Hada, M.; Ehara, M.; Toyota, K.; Fukuda, R.; Hasegawa, J.; Ishida, M.; Nakajima, T.; Honda, Y.; Kitao, O.; Nakai, H.; Klene, M.; Li, X.; Knox, J. E.; Hratchian, H. P.; Cross, J. B.; Adamo, C.; Jaramillo, J.; Gomperts, R.; Stratmann, R. E.; Yazyev, O.; Austin, A. J.; Cammi, R.; Pomelli, C.; Ochterski, J. W.; Ayala, P. Y.; Morokuma, K.; Voth, G. A.; Salvador, P.; Dannenberg, J. J.; Zakrzewski, V. G.; Dapprich, S.; Daniels, A. D.; Strain, M. C.; Farkas, O.; Malick, D. K.; Rabuck, A. D.; Raghavachari, K.; Foresman, J. B.; Ortiz, J. V.; Cui, Q.; Baboul, A. G.; Clifford, S.; Cioslowski, J.; Stefanov, B. B.; Liu, G.; Liashenko, A.; Piskorz, P.; Komaromi, I.; Martin, R. L.; Fox, D. J.; Keith, T.; Al-Laham, M. A.; Peng, C. Y.; Nanayakkara, A.; Challacombe, M.; Gill, P. M. W.; Johnson, B.; Chen, W.; Wong, M. W.; Gonzalez, C. Pople, J. A. Gaussian, Inc., Pittsburgh PA, 2003.

10. Wong. M. W. Chem. Phys. Lett. 1996, 256, 391.

11. Correlation Analysis in Chemistry, Chapman, N. B., Ed.; Shorter, J. Plenum Press: New York, 1978, pp 526-528.

12. (a) Overberger, C. G.; Biletch, H.; Finestone, A. B.; Lilker, J.; Herbert, J. J. Am. Chem. Soc. 1953, 75, 2078. (b) Applequist, D. E.; McGreer, D. E. J. Am. Chem. Soc. 1960, 80, 1965.

13. Frederickson, L. D. Anal. Chem. 1964, 36, 1349. 